\title{
O pensamento de Celso Furtado sobre Estado e planejamento
}

\author{
[Celso Furtado's thought about State and planning
}

Renato Nataniel Wasques ${ }^{\mathrm{I}}$

RESUMO - Estado e planejamento são temas recorrentes na vasta e original obra do economista brasileiro Celso Furtado (I9202004). Embora sejam elementos ubíquos, as remissões do autor ao Estado são, por vezes, pouco explícitas. Não há, em toda a sua obra, nem mesmo um só capítulo que contemple explicitamente uma discussão teóricoconceitual sobre o Estado. Isso, porém, não significa dizer que inexista uma explicação de Estado nos escritos do intelectual brasileiro. Nesse sentido, o objetivo deste artigo é desvelar e sistematizar o pensamento de Celso Furtado sobre Estado e planejamento. Para tanto, considera-se o conjunto da produção furtadiana, elaborada ao longo de seis décadas - de 1944 a 2004 -, pois se acredita que pouco se compreende quando se toma uma parte isolada da obra, sem levar em conta o desenvolvimento completo das ideias do autor. PALAVRAS-CHAVE Estado; planejamento e desenvolvimento; pensamento social brasileiro. A ABSTRACT .
State and planning are recurrent subjects in the vast and original intellectual production of Brazilian economist Celso Furtado (I9202004). Although they are ubiquitous elements, the author's references to the State are sometimes not very explicit. There is nothing in the entire author's work, not even a single chapter explicitly covering a theoreticalconceptual discussion about the State. This, however, does not mean that there is no explanation about the State in the writings of the Brazilian intellectual. In this sense, this article proposes to unveil and systematize Celso Furtado's thought about State and planning. In order to achieve this, Celso Furtado's whole work, produced over the course of six decades - from 1944 to 2004 - was taken into account, because it was believed that little is understood when an isolated part of the work is considered, without taking into account the complete development of the author's ideas. - KEYWORDS · State; planning and development; Brazilian social thought.

Recebido em I ${ }^{o}$ de setembro de 2020

Aprovado em Io de dezembro de 2020

WASQUES. Renato Nataniel. O pensamento de Celso Furtado sobre Estado e planejamento. Revista do Instituto de Estudos Brasileiros, Brasil, n. 78, p. I56-I8I, abr. 202I.

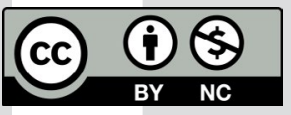

DOI: https://doi.org/Io.II606/issn.23I6-90IX.vIi78pI56-I8I

I Universidade Federal de Rondonópolis (UFR, Rondonópolis, MT, Brasil). 
Celso Furtado é um dos pensadores sociais brasileiros mais influentes de todo o século XX. Já há algum tempo passou à categoria de clássico, sendo considerado um autor indispensável para compreender e pensar o desenvolvimento e o subdesenvolvimento. Formação econômica do Brasil ilustra bem a sua influência. Tendo completado seis décadas de existência, esse clássico da historiografia econômica encontra-se na sua $34^{\mathrm{a}}$ edição e foi traduzido para nove idiomas.

São diversos os temas abordados pelo intelectual brasileiro. Alguns deles, incluindo o nosso objeto de estudo, constituem eixos temáticos essenciais da pesquisa do autor, atravessando o conjunto de sua produção intelectual. Assim, é lícito constatar que, já presente nos escritos de juventude, elaborados ainda nos anos I940, a temática do Estado e do planejamento alcançou lugar eminente nos trabalhos das décadas de I950, I960 e I970, figurando, também, nos seus últimos estudos, publicados no despertar do século XXI.

Embora sempre presente em suas reflexões, as remissões do autor ao Estado são, por vezes, pouco explícitas. No que respeita à formação do Estado na economia e na sociedade subdesenvolvidas, destaca Oliveira (2003, p. 65), "Furtado é mais evasivo", cabendo ao leitor a tarefa de "investigar [sobre o tema] no interior da trama que ele tece dos conflitos sociais, aí então descobrindo a riqueza de sua construção”.

Dessa forma, este artigo propõe desvelar e sistematizar as ideias de Celso Furtado sobre Estado e planejamento, atentando-se para os diferentes períodos da sua trajetória intelectual e política. Para tanto, considera-se o conjunto da produção furtadiana, elaborada ao longo de seis décadas - de I944 a 2004-, pois se acredita-se que pouco se compreende quando se toma uma parte isolada da obra, sem levar em conta o desenvolvimento completo das ideias do autor.

Assim, os aspectos metodológicos adotados nesta pesquisa fundam-se no exercício 
de ler a obra em si e por si mesma². Em outros termos, a ideia básica consistiu em deixar os textos "dizerem" por si próprios, mediante os seguintes procedimentos: a) identificar o modo de exposição usado pelo autor e respeitar as informações fornecidas por ele; b) observar a organização e a evolução das ideias do autor; c) verificar a cronologia histórica dos textos; d) acompanhar os movimentos sucessivos de construção e reconstrução das ideias do autor; e) captar o esforço de composição da moldura conceitual que ancora as análises histórico-teóricas do autor; f) perceber as circunstâncias e a época histórica em que os textos foram escritos, bem como a própria história biográfica do autor. Através desse procedimento metodológico, torna-se possível identificar elementos velados, aspectos ocultos e mensagens implícitas.

Tendo em vista apanhar os movimentos interpretativos no interior da obra furtadiana, optou-se pela temporalidade cronológica, também designada como temporalidade da produção dos textos, que permite identificar as continuidades e/ ou rupturas na forma como o autor abordou determinados temas, incluindo aqueles mais diretamente relacionados com esta pesquisa. Por meio da cronologia da obra, é possível acompanhar o ato mesmo de produzir os aportes teóricos, "de escrevê-los e reescrevê-los, de os montar e de os desmontar, montando-os novamente de outra forma” (BENOIT, 20I5, p. 24).

Para isso, a produção intelectual furtadiana foi organizada em cinco fases, as quais estruturam este artigo, a saber: escritos de juventude (I944-I948); interregno cepalino (I949-I958); interlúdio nordestino (I959-I964); escritos de maturidade (I965-I980); e escritos finais (I98I-2004).

\section{A CONCEPÇÃo ORIGINÁRIA}

No período I944-I9483, Celso Furtado preparou textos sobre administração, planejamento e democracia moderna. Alguns desses textos foram publicados na Revista do Serviço Público, ligada ao Departamento Administrativo do Serviço Público (DASP). Outros, porém, permaneceram inéditos por quase 70 anos, quando foram organizados e publicados por D’Aguiar (20I4).

Esses escritos já trazem os elementos essenciais que marcarão o método de investigação de Celso Furtado. Em primeiro lugar, destaca-se a importância

2 Desvela-se aqui a opção metodológica diferenciadora deste artigo, qual seja, a investigação sobre Estado e planejamento no pensamento furtadiano a partir dos próprios escritos do autor, deixando os textos “dizerem” por si próprios, sem a intermediação da literatura ou dos estudiosos do tema (leitura endógena da obra furtadiana). No entanto, é preciso registrar que esta estratégia metodológica não exclui o diálogo com a literatura existente, apenas indica o empenho em dar primazia aos próprios textos do intelectual brasileiro. Nesse sentido, o diálogo se dá, por exemplo, com Bielschowsky (2004), Brandão (2008), Cepêda (200I), Iglésias (I97I), Love (200I), Mallorquin (2005), Mantega (I984), Oliveira (2003), Paulani (200I), Ricupero (2005), Sampaio Jr. (2008) e Vieira (2005).

3 Essa fase abrange a trajetória inicial de Celso Furtado, compreendendo os seguintes ciclos: a universidade, o início de sua carreira de administrador público, a experiência no front e o período de formação na França, quando cursou o doutorado em economia. 
que o autor confere à dinâmica estrutural4, que culminará, anos mais tarde, numa visão diacrônica da realidade social, centrada no desenrolar dos acontecimentos no tempo. Em segundo lugar, sublinha-se o recurso à análise comparativa ${ }^{5}$, presente na maior parte dos textos aqui analisados, e que ocupará lugar de destaque nas suas obras de natureza teórico-histórica. Em terceiro lugar, vale salientar a aplicação do método histórico ${ }^{6}$, artifício metodológico que permitirá ao autor formar uma perspectiva globalizante da realidade social e dos problemas econômicos.

Além dos elementos de cunho metodológico, merece destaque a concepção de planejamento presente nos escritos de juventude. Ela se formou a partir do contato do autor com as ciências administrativas7; construiu-se, principalmente, com base no que ele aprendeu sobre os Estados Unidos ${ }^{8}$. Ou seja, o interesse por problemas organizacionais o levou a frequentar a literatura sobre administração. Foi a partir dessa literatura que ele chegou ao princípio fundamental, válido tanto para o setor privado quanto para o Estado, segundo o qual "não existe nenhuma ação possível sem planejamento" (FURTADO, 2008a, p. Io).

Essa primeira visão de planejamento, vinculada aos princípios organizacionais, e, por essa razão, restrita ao plano operacional e tecnicista, beneficiou-se da noção

4 Furtado (20I4a, 20I4b), por exemplo, além de descrever a hierarquia organizacional e as atribuições de dois importantes órgãos da administração pública estadunidense em um determinado instante no tempo, analisa as diversas transformações estruturais havidas ao longo dos anos, revelando, desse modo, importantes características e tendências da gestão de pessoal na administração federal americana.

5 "Esse procedimento investigativo, que privilegia a comparação como método capaz de esclarecer realidades através de contraposição e justaposição” (SILVA, 20Io, p. 94), aparece, por exemplo, na contraposição entre o movimento brasileiro de reforma administrativa, iniciado na década de I930, sob o regime Vargas, e a experiência estadunidense no campo da reforma da administração pública. A análise comparativa também se faz presente em Furtado (20I4e, 20I4h), cujo objeto de estudo é a organização dos governos municipais, quando o autor contrasta as experiências da Alemanha, Grã-Bretanha, Estados Unidos e Rússia.

6 A abordagem histórica é uma constante nos escritos de juventude, atravessando tanto os textos sobre administração pública quanto os estudos sobre ciência política. Ver: Furtado (20I4c, 20I4f, 20I4g).

7 Nas páginas de um diário, datado da então capital da República (Rio de Janeiro), I7 de dezembro de I945, Celso Furtado (20I9, p. 69) não deixa dúvidas de que chegara à ideia de planejamento a partir do estudo das técnicas de organização: "Eu há três anos que me dedico com todo carinho ao estudo da técnica de organização e orçamento. Estes estudos levam naturalmente a outros mais complexos, ou seja, planificação econômica e social".

8 Cinco décadas mais tarde, nos anos de I990, Celso Furtado (2008a, p. I2) deixaria o seguinte depoimento: “é curioso como se pensava na época que planejamento era coisa do socialismo. Na verdade, quem mais desenvolveu a ideia de planejamento foram os americanos”. 
mannheimiana de planificação democrática (planejar para a liberdade)’. A influência de Karl Mannheim sobre o pensamento de Celso Furtado é inequívoca. Por meio dela, Furtado pôde perceber que o planejamento é uma técnica social que permite disciplinar a ação e introduzir racionalidade na coisa pública, elevando, assim, o nível de eficácia das decisões que comandam o destino das nações. Além disso, permitiu que Celso Furtado se aproximasse da cultura humanística, percebendo que o planejamento não decorre apenas de uma boa estratégia, como ensinavam os princípios de administração, devendo, outrossim, ancorar-se num sistema de valores, para ser democrático. A partir desse momento, cristalizou-se no pensamento furtadiano a noção de planejamento como técnica social que "busca eliminar o perigo de dominação minoritária, e, portanto, é a solução para se conseguir o florescimento de uma cultura verdadeiramente democrática” (FURTADO, 20I4g, p. 2I5).

Com efeito, o planejamento passou a ser visto como um instrumento de ação reformadora, orientado para a reconstrução estrutural, condição básica para a edificação de uma sociedade democrática. Em outras palavras, o planejamento foi vinculado à ideia de ação transformadora, o que, nos escritos posteriores de Celso Furtado, significará uma ação voltada às modificações estruturais, condição sine qua non para se franquear a barreira do subdesenvolvimento. Ademais, essa visão de planejamento, forjada sob a influência do pensamento mannheimiano, revelou para o intelectual brasileiro a importância da ação estatal no processo de reconstrução social.

Essas considerações nos conduzem ao tema do Estado nos escritos de juventude de Celso Furtado. Nesse sentido, cumpre observar que o Estado é apresentado como "uma organização cujas forças estão coordenadas, parte pela simples pressuposição de objetivos comuns, parte por uma estruturação” (FURTADO, 20I4d, p. I45). O autor concebe o Estado em termos de Administração e Política, o que o conduz à discussão sobre racionalidade formal e substancial. Promove-se essa discussão para se evitar confusões entre meios e fins, que levam "um lado à inoperância administrativa, e por outro à imoralidade política” (FURTADO, 20I4d, p. I46). O autor ilustra esse problema nas seguintes palavras: "em alguns Estados democráticos a administração tem sido tratada por processos políticos - e disso resulta a sua baixa produtividade. Nos Estados fascistas, a política foi submetida a uma racionalidade formal e se tornou inumana" (FURTADO, 20I4d, p. I46).

Para evitar as confusões entre meios e fins, é fundamental ter em conta que o Estado "se estrutura internamente em uma Administração, que é o veículo pelo qual ele executa a sua Política” (FURTADO, 20I4d, p. I45). A Administração é, nesses termos, um meio para se alcançar um fim: a Política. Ela pertence à esfera da racionalidade formal, pois se apresenta como um organismo de execução, sofrendo a aplicação dos princípios de organização. $\mathrm{O}$ autor destaca que esse organismo desempenha uma dupla função: "entrar em contato com a vida social, sentir a sua realidade e elaborar o material sobre o qual se imprimirá a forma da Política, e executar o programa

9 Mannheim (I962, p. I8) sempre defendeu em seus trabalhos a prática do planejamento democrático, definido como "um mecanismo social que [une] os princípios da liberdade e da planificação, evitando de um lado o caos que surge nos processos sociais não planificados, e garantindo, de outro, que o poder e a expansão totalitária não serão tratados como fins em si mesmos". 
traçado pelo governo" (FURTADO, 20I4d, p. I45). A Política, por sua vez, é entendida como um conjunto de princípios formulados em função da coletividade ou grupo social, pertencendo, assim, ao campo da racionalidade substancial.

Nesse contexto, caberia perguntar: qual é o objetivo último do Estado? O seu fim é, segundo Furtado (20I4d, p. I45), "promover o bem-estar social”. Assim, o objetivo último do Estado relaciona-se ao âmbito da formulação de política, traduzindo-se na promoção do bem-estar social. Para o autor, esse fim só é alcançável regulamentando e coordenando a esfera do social, o que exige, evidentemente, o uso das técnicas de planejamento. $\mathrm{O}$ autor acrescenta que "a extensão dessa zona [social] regulamentada e o sentido da regulamentação [...] constituem a política do Estado" (FURTADO, 20I4d, p. I45).

Em síntese, o Estado é apresentado como um conjunto de elementos operando com unidade de ação e com propósito comum, cujas forças estão coordenadas com vistas a promover o bem-estar social. Assim, ressalta-se que unidade de ação e propósito comum presumem ações coordenadas, que, por seu lado, requerem o planejamento. Fica, pois, evidente a necessidade da presença constitutiva do Estado e do planejamento para estruturar estratégias concretas de reconstrução social. Isso significa que, para haver mudança estrutural e reconstrução social, é preciso que o planejamento se dê por ação do Estado.

Essas passagens trazem, em gérmen, a noção furtadiana, que se desenvolverá na década de I950, segundo a qual não pode haver desenvolvimento capitalista nacional sem a gestão do Estado, e que o processo de desenvolvimento só pode efetivar-se através de um esforço de planejamento global da economia, abrangendo a orientação e a coordenação dos processos de produção, distribuição e acumulação. Os trechos citados, portanto, já preconizam que a ação estatal é condição imprescindível para a luta contra o círculo vicioso do subdesenvolvimento.

Esboça-se, pois, a origem de uma importante faceta do sistema de pensamento furtadiano, que é fundamental para se pensar a ação estatal planejada nas sociedades e economias capitalistas. Trata-se da defesa de que, para funcionar, toda organização, incluindo o sistema econômico, não pode abster-se de certo grau de centralização, coordenação e controle de decisões. Essa ideia orientará toda a produção intelectual posterior de Celso Furtado, sobretudo aquela atinente às estratégias de superação do subdesenvolvimento, as quais exigem um conjunto de forças em concerto, pressupondo-se uma ampla e efetiva orientação estatal. Em suma, defende-se que a importância dada pelo autor à ação coordenada do Estado, instituição que na economia capitalista congrega, segundo ele, os centros de decisão mais importantes, tem sua origem nos estudos elaborados entre I944 e I948.

As ideias que apresentamos formam o que passaremos a chamar de concepção originária de Estado, a qual justifica a ênfase conferida pelo autor ao conceito de planejamento, ao passo que a discussão teórico-conceitual sobre o Estado está praticamente ausente. Nesse sentido, importa registrar que nos escritos de juventude não há nenhuma preocupação em explorar o processo histórico de formação do Estado, nem mesmo interesse em discutir teoricamente sua ação concreta, seja no tempo ou no espaço. A ênfase está no instrumento de ação, que é o planejamento, sendo o Estado o mecanismo que o viabiliza. Portanto, deduz-se que o Estado foi 
pensado, originariamente, sob as perspectivas instrumental, funcionalista e pragmática, sendo incomum qualquer aprofundamento teórico-conceitual.

\section{A CRÍtica AO LAISSEZ-FAIRE}

No período I949-I95 $8^{\text {Io }}$, Celso Furtado participou ativamente da confecção de pareceres técnicos e documentos oficiais, que vieram a público através das conferências organizadas pela Comissão Econômica para a América Latina (Cepal). Ao mesmo tempo, Celso Furtado publicou, tanto no Brasil como no exterior, vários trabalhos sob sua responsabilidade pessoal, incluindo livros, ensaios e artigos acadêmicos.

Nesses trabalhos, Celso Furtado coloca em xeque a tese de que o espírito de iniciativa e as forças dinâmicas da sociedade liberal são suficientes para promover a superação do subdesenvolvimento. Do seu ponto de vista, o progresso espontâneo apenas contribui para perpetuar o estado de pobreza relativa no qual se encontram as chamadas economias subdesenvolvidas. Ou seja, dentro dos marcos do Estado liberal, a situação de subdesenvolvimento tende a reproduzir-se indefinidamente, com agravação de sua posição relativa. $\mathrm{O}$ autor sugere, portanto, que o caminho capaz de promover a superação do subdesenvolvimento é essencialmente político, e que o Estado é o instrumento de que dispõe a sociedade para atuar politicamente.

Assim, ao rejeitar o laissez-faire, o autor reafirma a necessidade de "uma ação coordenadora" (FURTADO, I952, p. 35), haja vista que o desenvolvimento sem uma política bem concebida de programação do desenvolvimento é fonte importante de tensões estruturais e sociais, como a tendência permanente ao desequilíbrio externo, o processo inflacionário crônico e a concentração de renda cada vez mais aguda. Emerge dessa reflexão certa visão do desenvolvimento - a do desenvolvimento programado -, fruto da vontade política, e não algo que seja simples resultado das ditas forças que operam espontaneamente nos mercados.

Cabe, pois, concluir que o desenvolvimento econômico exige que se determinem critérios e que se definam escalas de prioridades; que se estabeleçam ações orientadoras e coordenadoras sobre o processo econômico; que se executem ações disciplinadoras sobre o conjunto dos investimentos; e que se tenha um mínimo de controle sobre as macrodecisões, vale dizer, as decisões que comandam a vida econômica nacional, e que têm sua origem nos centros de poder ${ }^{\text {II }}$. E como essas transformações deverão orientar-se no sentido da adoção de um efetivo planejamento,

Io Primeiro momento do autor como economista, quando integrou o staff técnico da Cepal. Foi nessa fase que ele entrou em contato direto com os problemas do desenvolvimento/subdesenvolvimento na maior parte dos países latino-americanos, experiência que lhe permitiu lançar as bases de sua teoria do subdesenvolvimento.

II Vê-se que, ao abordar a problemática da superação do subdesenvolvimento, o autor tem como referência básica os centros nacionais de decisão e coordenação, ou seja, ele o faz dentro de marcos políticos nacionais. 
a diretriz básica da política de desenvolvimento terá que ser o abandono de todas as formas de laissez-faire ${ }^{\text {I2 }}$.

Ademais, esses textos colocam em evidência a centralidade do Estado e do planejamento no sistema de pensamento de Celso Furtado. Não constitui nenhum exagero afirmar que o Estado é uma onipresença nas reflexões do autor. No entanto, o Estado em nenhum momento se constitui - pelo menos nos textos até aqui analisados - em objeto de tratamento teórico-conceitual aprofundado. $\mathrm{Ou}$ seja, inexiste qualquer tentativa de formulação teórica que leve em consideração a gênese, a formação, a estrutura e a evolução do Estado. Assim sendo, defende-se que o Estado é uma presença-ausente na obra do autor, isto é, constitui um elemento sempre reivindicado, ocupando posição de destaque em suas reflexões, mas que não chega a se transformar em objeto de investigação preferencial. Essa ausência de discussão teórica não deve, porém, ser vista como uma falha ou inconsistência do esquema de pensamento furtadiano, nem fruto de omissão por parte do autor. Tudo sugere, ao contrário, que essa presença-ausente está coerentemente relacionada com os seus propósitos de intelectual reformista e homem público a serviço da (n)ação ${ }^{\mathrm{I3}}$.

Para os propósitos do autor, essa formulação teórica se mostrou desnecessária, sendo suficiente limitar-se à análise do papel do Estado no processo de mudança social. Nesse particular, é lícito dizer que o objetivo do autor foi, justamente, chamar a atenção para o papel indispensável do Estado no processo de desenvolvimento capitalista nacional, reproduzindo, assim, o que chamamos de concepção originária de Estado. De resto, essa orientação justifica o esforço do pensador social brasileiro para avançar na compreensão da natureza da técnica de programação, que é o instrumento à disposição do Estado na luta contra a armadilha histórica do subdesenvolvimento.

Por fim, cumpre registrar que a singularidade dos textos publicados no interregno cepalino está na relação que o autor estabelece entre Estado, planejamento e desenvolvimento, apenas marginalmente explorada nos escritos de juventude. Uma relação que se traduz em verdadeiro otimismo quanto à capacidade do Estado em promover a superação do subdesenvolvimento e em levar adiante o esforço de construção nacional.

I2 Para evitar leituras equivocadas, é preciso deixar claro que Celso Furtado não está decretando o fim da iniciativa privada, mas apenas reconhecendo a inaptidão do laissez-faire em matéria de desenvolvimento econômico. Esse reconhecimento, diz ele, "não implica em pessimismo com respeito ao papel que o setor privado deve desempenhar no desenvolvimento" (FURTADO, I956, p. IOI).

I3 Para uma análise do perfil intelectual de Celso Furtado, ver: Wasques (2020). 


\section{DESENVOLVIMENTO, SUBDESENVOLVIMENTO E ESTADO}

No período I959-I9644 $4^{\mathrm{I} 4}$ as preocupações do autor ganham dimensões prioritariamente nacionais, voltando-se, sobretudo, para o problema das desigualdades regionais, em particular o da Região Nordeste. É quando o autor elabora a noção de que o subdesenvolvimento não é uma simples etapa pela qual tenham passado as economias que já alcançaram grau superior de desenvolvimento, devendo esse processo, ao contrário, ser compreendido como uma conformação estrutural coetânea do desenvolvimento, resultado da propagação da técnica moderna no processo de constituição de um sistema econômico de base mundial. Nas palavras do autor, tem-se que "o subdesenvolvimento é o reverso do desenvolvimento, constituindo os dois processos um todo" (FURTADO, I997b, p. 296).

Assim sendo, o subdesenvolvimento somente será superado caso sejam realizadas certas transformações estruturais, tendentes a corrigir as deformações inibidoras do dinamismo social. "Não se trata, apenas, de criar condições propícias a que os empresários intensifiquem seu esforço de inversão: é necessário dar um passo adiante, garantindo que as inversões provoquem as modificações estruturais requeridas pelo desenvolvimento" (FURTADO, I96I, p. 230-23I). Desse modo, tem-se que a luta pela superação do subdesenvolvimento exige uma estratégia baseada "numa racionalidade mais abrangente do que a dos mercados, e a ela só se tem acesso pelo planejamento" (FURTADO, I997a, p. 36). Em outros termos, o autor mostra que a superação do subdesenvolvimento só é possível no contexto de uma autêntica política de desenvolvimento, pois sem ela "os atuais países subdesenvolvidos continuarão a dar voltas no círculo vicioso da pobreza” (FURTADO, I962b, p.52).

\section{A AÇÃo estatal}

O problema do subdesenvolvimento não se resolverá espontaneamente, ao impulso dos mecanismos autocorretores de mercado. Trata-se de um problema que só poderá ser devidamente enfrentado por uma intervenção ativa do Estado na economia. Do laissez-faire não se pode esperar senão que perpetue e agrave o subdesenvolvimento. Nesse sentido, a luta pela superação do subdesenvolvimento "implica um processo político que a sociedade somente pode realizar por meio do Estado. Este é apenas um instrumento, e a sociedade é que decide como e com que fim utilizá-lo, consciente de que sem ele estará desarmada" (FURTADO, I997b, p. I84). À vista disso, percebe-se que o esforço para franquear a barreira do subdesenvolvimento não se faz sem a participação de amplos movimentos

I4 Esse período coincide com o segundo momento de Celso Furtado como economista, quando suas atividades se orientaram fundamentalmente, mas não exclusivamente, à área do Nordeste. Nesses anos, o autor atuou como planejador e executor da nova política de desenvolvimento econômico da região nordestina durante três governos consecutivos - Kubitschek, Quadros e Goulart. É por essa razão que qualificamos esses anos de "interlúdio nordestino". 
políticos, isto é, sem um projeto político esposado por amplos segmentos sociais e orquestrado à luz de princípios democráticos bem definidos.

Havendo compreendido que o subdesenvolvimento não deve ser aceito como fato de ordem natural, mas fruto de um processo histórico - portanto, passível de ser superado -, o autor empreende uma análise sobre as ações do Estado na luta pelo desenvolvimento. Nesse particular, ele sustenta que, "para desempenhar a função de promotor do desenvolvimento econômico, o Estado terá de adotar métodos diversos, conforme se trate de país de economia desenvolvida ou subdesenvolvida" (FURTADO, I962a, p. 48). Esse último fragmento é particularmente importante para os nossos propósitos, pois nele Celso Furtado preconiza o princípio, considerado corolário de sua teoria do subdesenvolvimento, segundo o qual as diferenças entre as estruturas desenvolvidas e subdesenvolvidas parecem ser suficientemente grandes para justificar o uso, pelo Estado, de métodos diversos para promover o desenvolvimento.

O princípio a que se fez referência é demonstrado pelo autor admitindo-se, para efeito de raciocínio, a hipótese de que os ideais de convivência social num país de economia desenvolvida assemelham-se aos que prevalecem em outro de economia subdesenvolvida. "Em ambos os casos", afirma ele, "aspira-se a conciliar o máximo de bem-estar econômico para a maioria e uma rápida melhoria nas condições de vida do povo com um sistema político baseado no máximo de liberdade pessoal" (FURTADO, I962a, p. 48). Em ambos os tipos de economia, os objetivos supremos da ação política são liberdade (democracia) e desenvolvimento econômico.

A análise dos métodos diversos à disposição do Estado na luta pelo desenvolvimento exige que exploremos, inicialmente, a diferença que o autor estabelece entre política quantitativa e qualitativa. Furtado (I962b) conceitua a política econômica quantitativa como aquela formulada com base em modelos macroeconômicos, com vistas a manter o pleno emprego da força de trabalho. Em outras palavras, a política quantitativa é definida como aquela que visa maximizar a eficiência do sistema econômico sem, contudo, alterar significativamente sua estrutura. Para o autor, a política de desenvolvimento numa economia capitalista desenvolvida é, principalmente, de caráter quantitativo.

A política econômica qualitativa, por seu turno, é aquela que visa promover modificações estruturais, a exemplo das chamadas reformas de base - agrária, fiscal, bancária e político-administrativa. O foco da política qualitativa está na remoção dos obstáculos institucionais e estruturais ao desenvolvimento capitalista autônomo. Ao preconizar importantes transformações estruturais, esse tipo de política desemboca no planejamento, isto é, "na tentativa de aumentar a racionalidade dos processos econômicos, identificando os pontos de bloqueio responsáveis pela má utilização de recursos escassos" (FURTADO, I997a, p. I83). É o tipo de política que melhor se adéqua às estruturas pouco diferenciadas e aos sistemas de baixo grau de integração, isto é, às economias subdesenvolvidas.

Nessas economias, a estabilidade do sistema econômico ao nível de pleno emprego do capital instalado não é uma condição suficiente para alcançar os objetivos básicos do desenvolvimento. Isso ocorre porque a economia subdesenvolvida padece de um desequilíbrio estrutural ao nível dos fatores - uma situação em que a plena utilização do capital é insuficiente para a completa absorção da força de trabalho. Assim, nos 
países de economia subdesenvolvida, a política de desenvolvimento requerida é de natureza qualitativa. Isso quer dizer que a liquidação do subdesenvolvimento implica transformação global da sociedade, ou melhor, pressupõe complexo esquema de coordenação, que só pode ser realizado através do planejamento.

Em contraste com as economias desenvolvidas, nas quais é suficiente adotar métodos indiretos de intervenção estatal, nas economias subdesenvolvidas torna-se indispensável a ação planejada do Estado, na amplitude exigida por uma política de desenvolvimento de natureza qualitativa. Fica, pois, evidente que o planejamento é o instrumental de que dispõe o Estado, em um país subdesenvolvido, para realizar suas funções no campo do desenvolvimento econômico. Ou seja, o planejamento é concebido pelo autor como esforço ordenador da ação do Estado na busca pelo desenvolvimento, sem o qual as reformas de estrutura seriam inalcançáveis. Desse ponto de vista, pode-se argumentar que o Estado nas economias subdesenvolvidas é instituição sui generis ${ }^{15}$, visto que sua função aparenta ser muito mais ampla e complexa do que conheceu o Estado nas estruturas desenvolvidas. A conclusão a que chegou o autor é a seguinte: "se bem sejam os mesmos os ideais de convivência em sociedades democráticas, de economias desenvolvidas ou subdesenvolvidas, as funções do Estado, instrumento principal da consecução daqueles ideais, podem ser distintas" (FURTADO, I962a, p. 50).

Com o que foi exposto, pretendeu-se reiterar que o subdesenvolvimento, sendo um caso especial na evolução capitalista, não deve ser interpretado como uma etapa necessária da trajetória de desenvolvimento das nações. Sendo um fenômeno específico, o subdesenvolvimento possui características próprias, que diferem das estruturas desenvolvidas. Em razão dessas diferenças estruturais, as funções e os métodos de intervenção à disposição do Estado na luta pelo desenvolvimento também diferem grandemente. Para desenvolver-se, cada estrutura econômica exige métodos de intervenção específicos às suas necessidades, isto é, políticas de desenvolvimento próprias.

\section{O PROCESSO DE MUDANÇA SOCIAL}

Ao longo desta subseção, objetiva-se demonstrar que, em Celso Furtado, o Estado, além de importante agente promotor do desenvolvimento econômico, é, principalmente, resultado de processos específicos de cada experiência histórica de (sub)desenvolvimento. Para tanto, levar-se-á em consideração a análise de Furtado (I964) sobre o mecanismo e a dinâmica do desenvolvimento nas sociedades capitalistas, uma análise que tem como fundamento o conceito de mudança social,

I5 É importante registrar que o grau de intervenção preconizado por Celso Furtado é perfeitamente compatível com o padrão de sociedade democrática que vimos aperfeiçoando no mundo ocidental. Assim, é preciso ter claro que democracia, planejamento e desenvolvimento não são termos antitéticos no pensamento furtadiano, encerrando, ao contrário, ampla compatibilidade. Basta lembrar que o autor, quando pensa o planejamento, tem sempre presente a noção mannheimiana de planificação democrática. 
que surge no campo das ciências sociais como reação contrária ao caráter teleológico da ideia de progresso, cara ao século XIX.

Tendo em vista descrever o processo de desenvolvimento no contexto de mudança social, Furtado (I964) propõe um modelo dinâmico de rápidas modificações tecnológicas, admitindo que as mudanças sociais têm sua causa primária na introdução de inovações tecnológicas, que podem originar-se na própria cultura, ou ser absorvidas de outras culturas. O modelo elaborado pelo autor pressupõe que a introdução de inovações em algum elemento básico de uma cultura tende a repercutir em toda a estrutura social. Por trás desse raciocínio, tem-se claramente configurada a ideia de interdependência entre os distintos elementos materiais e não materiais que integram um sistema cultural ${ }^{\text {t6 }}$.

O modelo permite identificar aquelas inovações que não provocam modificações permanentes no sistema social, bem como aquelas outras tipicamente de caráter dinâmico. $\mathrm{O}$ autor argumenta que as mudanças introduzidas na esfera da cultura material - isto é, nos processos produtivos - por inovações tecnológicas apresentam características sui generis. "Essas mudanças são necessariamente de caráter dinâmico, tendendo a provocar reações em cadeia” (FURTADO, I964, p. 25). As mudanças nos aspectos da cultura não material, por sua vez, são mais lentas do que as transformações no sistema de produção. Isso explica "que nas épocas de rápida absorção de inovações possa haver grandes tensões psicossociais” (FURTADO, I964, p. 26).

Em realidade, as inovações tecnológicas introduzidas na cultura material, em razão da série de reações que provocam, têm a faculdade de condicionar todo o processo de mudança social. A mensagem transmitida pelo modelo é bastante clara, a saber: a introdução de inovações tecnológicas no sistema de produção, ao modificar um parâmetro no sistema social, põe em marcha uma série de reajustamentos e acomodações, que, por sua vez, não se efetiva sem provocar resistências e reações contrárias, e estas, quando existe a propriedade privada dos meios de produção, se manifestam através de conflitos sociais.

Assim, da ideia de mudança social parte-se para a de conflito entre classes e de resistência à mudança. Tais conflitos resultam, segundo o autor, "da busca consciente, pelos membros de uma sociedade, de valores que se excluem" (FURTADO, I964, p. 27). Nas sociedades capitalistas, os conflitos resultantes da introdução de inovações na esfera material da cultura tendem a assumir a forma de conflitos de classes sociais antagônicas.

Até que ponto as observações que fizemos nos conduzem ao tema do Estado no pensamento furtadiano? $\mathrm{O}$ autor abre espaço para abordarmos este tema quando afirma que as inovações tecnológicas não provocam apenas modificações na base material da cultura, mas também na superestrutura de valores sociais, haja vista a interdependência que existe entre esses elementos. Em seu modo de ver, "as

I6 Para construir esse modelo, Furtado (I964) baseia-se na teoria das mudanças sociais, formulada por autores como B. Malinowsky, W. F. Ogburn, M. Herskovits e E. Hagen, que concebem a cultura como um sistema constituído de elementos interdependentes. Assim, o sistema é dividido em cultura material (processos de produção, tecnologia etc.) e cultura não material (organização social e política, ciência, arte, religião, moral, costumes etc.). 
mudanças na estrutura econômica tendem a acarretar modificações em toda a estrutura social, o que ocorre não como uma causação simples, mas em função de determinadas condições históricas" (FURTADO, I964, p. 29). É sabido que entre os elementos da cultura não material encontra-se o Estado, que, como quaisquer outros aspectos da superestrutura de valores sociais, terá de ajustar-se toda vez que em determinadas condições históricas avança a tecnologia e se desenvolvem as bases materiais da cultura.

Nesse sentido, desde já se levanta a hipótese de que, talvez, em Furtado, o Estado, sendo um aspecto da cultura não material, é principalmente reflexo (resultado) dos avanços que se observam no âmbito da estrutura econômica - cultura material. Não se trata, porém, de relação estritamente unidirecional, porque, como enfatizado pelo próprio autor, a cultura não material muitas vezes exerce importante influência sobre a estrutura econômica.

O que o autor parece ter implícito em seu pensamento é que o Estado, assim como os demais componentes da cultura não material - estruturas social, política e institucional -, é chamado a ajustar-se toda vez que avançam as bases materiais do sistema cultural. Ao ajustar-se, provoca, por sua vez, outra série de novas reações com efeitos inclusive sobre a estrutura econômica. Assim, por um lado, dever-se-ia entendê-lo como resultado (efeito) da interação dialética entre o desenvolvimento das bases materiais e o consequente ajustamento dos aspectos não materiais da cultura; por outro, como elemento determinante (causa) de importantes transformações, pois, ao acomodar-se às novas condições históricas, o Estado tende a condicionar o próprio desenvolvimento das bases materiais da cultura.

Ademais, é importante registrar que o processo de interação dialética entre as esferas material e não material do sistema de cultura é bastante distinto, conforme se trate de países desenvolvidos ou subdesenvolvidos. De acordo com Furtado (I964, p. 29), "nas economias chamadas subdesenvolvidas, o processo de ajustamento da estrutura social ao fluxo de mudanças decorrentes da assimilação de uma nova tecnologia apresenta uma série de peculiaridades que o distinguem do modelo corrente do desenvolvimento capitalista". Se é verdade que o Estado decorre daquele processo, então se explica a diversidade de formas que o Estado tende a assumir em diferentes estruturas sociais e econômicas. Fica, pois, evidente que o Estado não é homogêneo no espaço, assumindo, ao contrário disso, formas diversas, tratando-se de país de economia desenvolvida ou subdesenvolvida.

Essa conclusão tem como fundamento a análise furtadiana sobre o papel das lutas de classes no desenvolvimento das instituições políticas. Nessa análise, o autor apresenta o Estado como a mais poderosa organização dentro de uma sociedade, cujo poder "se legitima pelo fato de que a coletividade vê naqueles que o exercem os árbitros de seus interesses, e se efetiva porque aqueles que o detêm possuem o comando da máquina do Estado" (FURTADO, I964, p. 38).

Ao penetrar mais a fundo nessa matéria, o autor abandona o ponto de partida de Friedrich Hegel (I770-I83I), que havia estabelecido uma marcada diferenciação entre os conceitos de Estado e de Sociedade Civil. A esse respeito, escreveu: "Hegel idealizou o Estado e esvaziou-o de todas as funções comuns de agente prestador de serviços, funções essas que ele imaginava podiam ser desempenhadas pela sociedade civil 
organizada” (FURTADO, I964, p. 37). O autor segue dizendo que seria muito difícil imaginar uma estrutura social que tenha alcançado certo grau de diferenciação sem a existência dentro dela de uma autoridade coatora, "o que vem a ser um Estado" (FURTADO, I964, p. 37). E conclui essa reflexão chamando a atenção para o caráter sui generis dessa organização política: "cabendo-lhe o monopólio do uso da força em nome da coletividade como um todo" (FURTADO, I964, p. 37).

Além disso, o autor abandona a visão de Friedrich Engels (I820-I895), segundo a qual o Estado moderno é exclusivamente o instrumento de opressão a serviço de uma classe. Diz ele: "como a mais poderosa organização dentro de uma sociedade, é perfeitamente natural que o Estado venha a desempenhar em muitas oportunidades um papel autônomo nos conflitos que caracterizam o desenvolvimento dessa sociedade" (FURTADO, I964, p. 38). Em outro trecho, reitera que "essa enorme organização [que é o Estado] tende a constituir, em uma sociedade dividida em classes, um estrato autônomo dessa sociedade, com aspirações e atitudes que não têm por que confundir-se sempre com as das classes em conflito" (FURTADO, I964, p. 40). Mais à frente, conclui: "seria um engano ver [no Estado] aquela 'força de repressão' a que se referiu Engels tantas vezes” (FURTADO, I964, p. 79).

De acordo com Furtado (I964), o desenvolvimento do capitalismo industrial - ou seja, das bases materiais da cultura - repercutiu de duas formas na configuração das organizações políticas: I) a maior instabilidade interna decorrente das lutas de classes se traduziu numa atividade política muito mais intensa, com participação de setores bem mais amplos da coletividade, vale dizer, exigiu a criação de estruturas políticas muito mais flexíveis e, a fortiori, mais representativas (democráticas); 2) o enriquecimento da sociedade fez ampliar as necessidades coletivas, o que se traduziu em crescimento substancial do aparelho estatal prestador de serviços e regulador dos processos econômicos. A análise atenta dessas duas forças permite perceber que as diferentes formas assumidas pelo Estado moderno são resultado da interação entre as esferas material e não material de um sistema de cultura.

Nesse sentido, o autor argumenta que o crescimento do aparelho estatal foi a "resultante das transformações que a estrutura social estava sofrendo como decorrência do desenvolvimento das forças da produção" (FURTADO, I964, p. 40). Esse trecho é particularmente importante, pois corrobora a hipótese segundo a qual o Estado é, principalmente, a resultante de processos específicos de cada experiência histórica de desenvolvimento.

Percebe-se que o autor logrou ir além das perspectivas instrumental e funcional-pragmática de Estado, superando, assim, a chamada concepção originária. Os escritos examinados representaram, sem qualquer dúvida, uma verdadeira descontinuidade na forma como o autor vinha concebendo o Estado, que deixou de ser visto apenas como um "agente externo", que sempre é reivindicado para intervir na realidade social, mas que jamais se transformava em objeto de estudo, passando a ser concebido, também, como produto da interação dialética entre o desenvolvimento das bases materiais e o consequente ajustamento dos aspectos não materiais da cultura.

Assim, foi possível demonstrar que o Estado, além de promotor do desenvolvimento econômico - causa -, é, principalmente, a resultante de processos específicos de cada experiência histórica de desenvolvimento - efeito -, e, em virtude disso, são esses 
processos históricos específicos, que têm suas raízes na expansão internacional do capitalismo industrial, que ganham destaque - isto é, são postos no centro da análise - ou seja, que merecem a atenção de Celso Furtado.

A conclusão anterior nos remete à noção de Estado como uma presença-ausente no sistema de pensamento furtadiano. Agora, porém, não se trata de ausência de aprofundamentos teóricos, conforme preconizado na seção anterior. Ao contrário disso, a noção de presença-ausente é aqui reivindicada para sinalizar a existência de uma explicação de Estado nos escritos do interlúdio nordestino, mas que não chega a formar um corpo teórico explícito, permanecendo como um aspecto oculto na obra do autor. O que se fez para explicitá-la foi esquadrinhar cuidadosamente as análises do autor sobre os efeitos da propagação do capitalismo industrial, difusão que moldou diversos mecanismos ou forças que estão na base da dinâmica social. Isso quer dizer que há uma explicação de Estado, mas ela está implícita, exigindo do pesquisador uma leitura atenta das passagens relativas aos mecanismos responsáveis pelos processos de mudança social. Defende-se que o estudo desses mecanismos é a essência mesma do aparato teórico-analítico furtadiano.

\section{A TRANSNACIONALIZAÇão do CAPITALISMO}

No período I965-I980 ${ }^{\mathrm{I7}}$, Celso Furtado introduz um novo tema ao seu escopo de pesquisa, a saber: o processo de transnacionalização do capitalismo - também chamado pelo autor de capitalismo de grandes unidades - e seus efeitos sobre as economias subdesenvolvidas.

Nos escritos dessa fase, o autor demonstra que a principal consequência da penetração do capital transnacional nas economias subdesenvolvidas tem sido, sem dúvida, o esvaziamento dos Estados nacionais como centros de decisão e como importantes instrumentos do desenvolvimento. Uma vez nessas economias, as organizações de ação transnacional passam a controlar grande parte das decisões econômicas em setores estratégicos, incluindo a orientação dos investimentos, a localização das atividades econômicas, a orientação da tecnologia, o financiamento da pesquisa e o grau de integração das economias regionais. Com efeito, "o governo torna-se cada vez mais impotente em face dessas grandes empresas" (FURTADO, I968, p. 43).

As grandes empresas são colocadas numa posição de poder vis-à-vis os Estados nacionais. Em outras palavras, é possível dizer que essas empresas passaram a disputar com o Estado a posição de centro de decisões fundamental na economia capitalista. Eis algumas razões: I) as grandes empresas controlam a inovação dentro das economias nacionais; 2) elas são responsáveis por grande parte das transações internacionais; 3) operam internacionalmente sob orientação que escapa em grande parte à ação isolada de qualquer governo; e 4) preservam uma grande liquidez fora do

I7 Terceiro momento do autor como economista, quando se dedicou ao ensino e à pesquisa em universidades europeias e americanas. Nessa fase, observa-se uma preocupação constante do autor com as premissas científicas, com o arcabouço teórico da ciência econômica e sua capacidade para dar resposta aos grandes problemas sociais e econômicos. 
controle dos bancos centrais e têm fácil acesso ao mercado financeiro internacional. Vê-se que a empresa de ação transnacional goza de efetiva autonomia, a qual decorre do fato de que ela "tem à sua disposição recursos de poder que podem liberá-la, ainda que parcialmente, da ação constritiva exercida pelos centros coordenadores nacionais" (FURTADO, 2008b, p. 40).

Furtado (2000) complementa esse raciocínio, argumentando que as grandes empresas, com sede nos centros dominantes, ao manipular o fluxo de novas técnicas e de novos produtos, participam, crescentemente, das atividades econômicas dos países subdesenvolvidos, contribuindo para recrudescer as relações de dependência externa e, por conseguinte, para perpetuar a situação de subdesenvolvimento. Em consequência, esses países "viram seus sistemas econômicos subordinarem-se de forma progressiva aos centros de decisão que comandam os projetos de expansão de empresas estrangeiras" (FURTADO, 2000, p. 338).

Assim sendo, o controle de parte do sistema de decisões que comanda a atividade econômica, por grupos estrangeiros, contribuiu, como mostra Furtado (I969), para desarticular as economias nacionais, reduzindo, assim, a possibilidade de uma efetiva coordenação interna das decisões econômicas motoras. A propósito disso, assevera: "não obstante a expansão relativa das atividades econômicas do setor público, os Estados latino-americanos possuem hoje menos capacidade para orientar as economias nacionais respectivas, do que era o caso dois decênios atrás" (FURTADO, I969, p. II6).

Nesse sentido, as empresas transnacionais são vistas como um instrumento inadequado para enfrentar o subdesenvolvimento. Para o autor, a grande organização só pode contribuir para congelar o status quo social, uma vez que, ao penetrar numa economia subdesenvolvida, gera efeitos "similares aos de certas grandes árvores exóticas que são introduzidas em determinadas áreas: drenam toda a água e dessecam o terreno, provocando um desequilíbrio na flora e na fauna, a emergência de pragas e outras coisas parecidas" (FURTADO, I968, p. 45).

As observações anteriores revelam os limites impostos aos centros nacionais de decisão pela presença da empresa transnacional. Para reverter esse quadro de perda de autonomia, o autor defende a necessidade de reabilitação do Estado nacional como centro coordenador das decisões econômicas estratégicas ${ }^{18}$, para transformar a articulação multinacional em efetivo instrumento do desenvolvimento. "Sem essa recuperação", conclui ele, "é de prever que continue a agravar-se a desarticulação das economias nacionais e que persista o impasse da estagnação" (FURTADO, I969, p. II7).

Para assegurar que empresas estrangeiras pautem o seu comportamento pelas diretrizes estabelecidas pelos órgãos orientadores da economia nacional, várias recomendações foram apresentadas pelo autor. São sugestões que indicam o sentido que poderia tomar a ação política voltada a afetar os vínculos de dependência. Essas sugestões apontam que, diante do poder representado pela empresa transnacional, a única resposta racional é acionar e/ou valorizar os centros de poder representados

I8 Essa passagem mostra que o autor não abandona a noção segundo a qual a superação do subdesenvolvimento requer a criação de um sistema econômico articulado e capacitado para autodirigir-se, vale dizer, de um autêntico sistema econômico nacional. 
pelo Estado, uma vez que esses centros são os únicos capazes de sujeitar o capital transnacional aos interesses da economia nacional. Na verdade, o que Furtado (2008b) propõe são mecanismos orientados para ampliar a parte do excedente social apropriada pela coletividade local, passando pelo controle da tecnologia, das finanças, dos mercados, do acesso aos recursos não renováveis e à mão de obra barata. A análise do autor leva a perceber que o Estado tem a faculdade de influir na utilização do excedente, abrindo, assim, o caminho ao verdadeiro desenvolvimento.

O Estado é, assim, reivindicado para exercer o papel de diretor da vida social, não obstante os limites trazidos pela emergência da empresa transnacional como importante centro de poder nas relações econômicas internacionais. Em uma entrevista concedida a Claudio Cerri, em junho de I975, Celso Furtado é explícito sobre esse ponto, afirmando que "tudo isso não impede que o Estado continue tendo um papel importantíssimo e uma responsabilidade cada vez maior na gestão geral da sociedade" (FURTADO, 2008b, p. 254). Assim, o que importa frisar é que o autor conserva certo otimismo quanto à capacidade do Estado em acicatar o processo de desenvolvimento capitalista autônomo, não obstante a transnacionalização do capitalismo observada nos anos I960 e 70.

Só se compreende essa insistência quando se tem em conta que o autor jamais aceitou a ideia de necessidade histórica com sentido imanente, uma vez que percebia o histórico como um processo contingente, aberto e em construção. A respeito disso, afirmou que, "quando a sociedade, ou segmentos desta, reage à asfixia criada pelo uso do poder [exercido pela grande empresa], as ondas que se levantam repercutem nas estruturas do Estado, de onde ocasionalmente partem iniciativas corretivas" (FURTADO, I974, p. 57). Ou seja, o autor defende que o processo histórico deve ser visto como um movimento aberto, e não como um determinismo, nem como uma necessidade lógica, vale dizer: "o que vai acontecer em cada país dependerá em parte substancial do comportamento de seu povo e de seu governo" (FURTADO, 2003, p. 3).

Nos escritos de maturidade, o autor também se dedica ao estudo da natureza do Estado nos países de capitalismo periférico. A hipótese central apresentada por Furtado (I976, p. 98) é a de que "o Estado que foi emergindo nos países de capitalismo periférico na fase de industrialização é instituição de alguma forma sui generis. Suas responsabilidades diretas no plano econômico são bem maiores do que as que conheceu o Estado no capitalismo central até o presente". Cabe salientar que, por trás dessa hipótese, estão duas ideias que permeiam o aparato teórico-analítico furtadiano, as quais explicitamos anteriormente: I) o Estado assume formas diversas, tratando-se de estruturas desenvolvidas ou subdesenvolvidas; e 2) para desempenhar o papel de promotor do desenvolvimento econômico, o Estado terá de adotar métodos igualmente dissímeis.

Segundo sua análise, o Estado que emergiu no quadro do capitalismo periférico se transformou não apenas em principal fonte de financiamento, mas, também, no agente econômico que assume o esforço de acumulação mediante investimentos em infraestrutura e outros de longa maturação. Assim, nas economias e sociedades subdesenvolvidas, a necessidade de intensificar o esforço de acumulação exige uma mais ampla e complexa ação do Estado, o qual se apresenta como o principal instrumento de captação de recursos financeiros, controlando diretamente empresas 
de grande porte, associando-se a grupos estrangeiros e exercendo o poder regulador. Finalmente, o intelectual brasileiro sustenta que o capitalismo periférico é um tipo de formação social e econômica que "requer maior concentração de poder e maior interdependência entre o político e o econômico do que foi a regra na evolução do capitalismo central” (FURTADO, I976, p. 98).

Os escritos examinados nesta seção revelaram uma preocupação constante do autor com respeito à evolução estrutural do sistema capitalista na fase de predomínio das empresas transnacionais. Nesses textos, o autor examina tanto a gênese e a natureza da empresa transnacional quanto as consequências da penetração desse novo tipo de organização nas economias e sociedades subdesenvolvidas. Isso, porém, não significa que o autor abandona a perspectiva que elege o Estado como vetor fundamental da mudança social. Apenas indica uma mudança de ênfase, ou seja, mostra que sua preocupação recaiu sobre outra problemática - qual seja, o processo de perda de autonomia do Estado nacional em face da transnacionalização da economia -, cujo tratamento tornou-se mais premente para a compreensão dos problemas específicos que assolam as economias subdesenvolvidas na época contemporânea.

\section{AINDA EXISTE ESPAÇO PARA O ESTADO PLANIFICADOR?}

No período I98I-2004 $4^{\text {I9 }}$, o autor publicou diversos trabalhos que trazem uma obstinada defesa da necessidade de ganhar poder de comando sobre os centros internos de decisão. Assim, objetiva-se mostrar que Celso Furtado não perdeu a fé na possibilidade de criar e fortalecer centros endógenos de decisão, capazes de disciplinar o capital transnacional, a fim de colocá-lo a serviço dos desígnios da sociedade nacional. Para ele - e este é um ponto fundamental -, o fortalecimento dos mecanismos nacionais de regulação e coordenação apresenta-se como um caminho de resistência ante as forças que operam planetariamente no sentido de desarticulação dos sistemas econômicos nacionais.

Nesse sentido, ressalta-se que, em pleno vigor da chamada globalização e em plena hegemonia do pensamento neoliberal, o autor continuou acreditando na viabilidade do capitalismo regulado. Mas não se trata de qualquer tipo de capitalismo. Nos escritos finais, o autor sustenta que já não é possível continuar reproduzindo os traços característicos do capitalismo herdado dos últimos dois séculos, enfatizando a urgência de alterar o curso da civilização criada pela revolução industrial. É por esse caminho que ele retoma a discussão sobre Estado e planejamento, mas, agora, o faz a partir de uma reflexão sobre o estilo de desenvolvimento e o formato que deverá assumir o próprio capitalismo.

Seus últimos estudos evidenciam os limites do padrão de desenvolvimento capitalista baseado na assimilação, por uma pequena minoria da humanidade, dos padrões de vida engendrados pelos países que lideraram o processo de

I9 Quarto momento do autor como economista, quando ele retornou efetivamente ao Brasil, após os anos de exílio, reinserindo-se na vida política nacional. Essa é uma fase de reflexões, balanços e sínteses, dedicada à organização de suas memórias intelectuais. 
industrialização, e apontam para a necessidade de reorientação desse padrão de desenvolvimento. Em outras palavras, o autor radicaliza a crítica aos fundamentos da civilização industrial, denunciando o caráter elitista, insustentável e antissocial do modelo de desenvolvimento cujo dinamismo é derivado da reprodução mimética do padrão de vida dos países centrais, privando parcela importante da população dos meios de vida essenciais, posto que altamente concentrador de riqueza em benefício de uma minoria.

Assim, tendo revelado a natureza excludente do padrão de desenvolvimento criado pelo capitalismo industrial, o autor passa a defender uma mudança radical rumo a um modelo que seja ecologicamente sustentável ${ }^{20}$, socialmente justo e politicamente democrático. Trata-se do desafio de encontrar um novo caminho, que viabilize o verdadeiro desenvolvimento, entendido como um processo inventado no próprio país, mediante a incorporação da questão ecológica e com base no patrimônio histórico-cultural que cimenta a identidade nacional.

Independentemente dos caminhos a trilhar, o objetivo estratégico consiste em reforçar a esfera política - recuperar a ação reguladora do sistema político-, ou seja, aumentar o poder regulador das atividades econômicas, única forma de colocá-las a serviço dos interesses sociais. De qualquer modo, o autor argumenta que, "para escapar ao sistema de forças que se articulam planetariamente, é necessário que se conjugue uma vontade política fundada em amplo consenso social com condições objetivas" (FURTADO, I992b, p. 58).

Emerge daí um novo e ciclópico desafio ao planejamento estatal, exigindo, inclusive, uma mais ampla e sofisticada ação do poder público para substituir o velho modelo de desenvolvimento, baseado no mimetismo de padrões culturais, por outro, voltado para a economia dos recursos não renováveis, para a redução do desperdício e para a solução do problema das desigualdades sociais. Os novos desafios são, por conseguinte, de natureza política e social-ecológica, e pressupõem a conquista de maior homogeneidade social.

Sendo assim, entende-se que somente a vontade e a ação política, aliadas à criatividade e inventividade do povo, poderão descortinar novos caminhos, alternativos aos que foram engendrados pela civilização industrial, cujo caráter predatório é cada dia mais inequívoco. Todas essas transformações presumem a reciclagem profunda das estruturas endógenas de poder, entre as quais se incluem os centros de decisão representados pelo próprio aparelho estatal, que deverá reestruturar-se e ajustar-se às mudanças estruturais trazidas pelo processo de globalização produtiva e financeira, mudanças "que se traduzem por crescente concentração da renda e por formas de exclusão social que se manifestam em todos os países" (FURTADO, I999a, p. 26).

Ao refletir sobre o novo modelo de desenvolvimento, o autor é ainda mais enfático quanto à importância do Estado para reorientar o curso dos acontecimentos e ativar as potencialidades criativas da sociedade. Ou seja, uma vez mais o Estado é reivindicado como o instrumento privilegiado para enfrentar os problemas

20 Para uma síntese da visão de Celso Furtado sobre a questão ambiental, ver Wasques, Santos Júnior e Brandão (20I9). 
estruturais, não no sentido de reproduzir o estilo de vida dos países centrais, mas no de trilhar caminhos alternativos, construídos a partir das prioridades definidas pela própria coletividade. Em suma, tem-se que a superação do subdesenvolvimento só é factível no âmbito de um projeto nacional, pensado "desde dentro", devendo apoiar-se numa verdadeira política nacional de desenvolvimento.

Para tanto, é imprescindível um exercício permanente de imaginação e criatividade política no sentido de reforçar e reestruturar o Estado, capacitando-o para responder ao desafio de conduzir o processo de desenvolvimento no contexto do capitalismo global. Trata-se da necessidade de um movimento político-criativo que fortaleça os vínculos de solidariedade histórica para preservar a identidade cultural e a unidade política, evitando, assim, o processo de fragmentação da unidade nacional. Isso significa que a política de desenvolvimento deve contemplar, também, uma política cultural, não para fomentar o consumo de bens culturais importados, mas para liberar as forças criativas da sociedade, abrindo espaço para que essas forças floresçam. Nesse sentido, importa assinalar que o processo de reconstrução de estruturas avariadas deve ser visto como um esforço liberador de energias criativas.

Todas essas transformações pressupõem a reciclagem do próprio aparelho estatal, que deverá ajustar-se às mudanças estruturais trazidas pelo processo de globalização produtiva e financeira. Cumpre observar que, sem esse esforço de reestruturação e renovação do Estado, dificilmente essa instituição estará em condições de assumir o desafio de promover o desenvolvimento no quadro histórico do capitalismo global.

No contexto do capitalismo global, dominado por grupos transnacionais e marcado pela primazia financeira, o Estado é chamado a assumir um papel ainda mais amplo e sofisticado, posto que ele "é o mais importante instrumento que uma sociedade tem para agir sobre ela mesma” (FURTADO, I998, p. 7I). Para captar essa importância ainda maior da ação estatal na fase atual da evolução do capitalismo industrial, torna-se necessário ter presente que o capitalismo global contribuiu para reforçar a dependência cultural, que está na origem e na persistência do subdesenvolvimento.

Nesses termos, o autor reafirma a importância da ação estatal na busca pelo desenvolvimento, não obstante a hegemonia da tese de que "o processo de globalização dos mercados há de se impor no mundo todo, independentemente da política que este ou aquele país venha a seguir" (FURTADO, I999a, p. 26). Segundo sua análise, equivoca-se quem imagina que já não existe espaço para o exercício de uma política nacional de desenvolvimento, apoiada na expansão do mercado interno. No seu último livro, Celso Furtado argumenta que "temos que voltar à ideia de projeto nacional, recuperando para o mercado interno o centro dinâmico da economia" (FURTADO, 2002, p. 42).

Essas observações deixam transparecer que o autor rejeita a tese de dissolução do que se entende por Estado nacional, sustentando que "é uma ilusão imaginar que a necessidade de governar vá diminuir com a globalização” (FURTADO, I998, p. 74). Isso está bem colocado em uma de suas últimas entrevistas, que traz a seguinte declaração: "não há dúvida de que a globalização dos fluxos monetários e financeiros deve ter como contrapartida um aparato de medidas disciplinadoras em cada país, 
e isso exige a preservação e o aperfeiçoamento constante das instituições estatais” (FURTADO, 2004, p. 3).

Assim, é lícito dizer que, outra vez, o autor argumenta que as transformações estruturais exigidas para promover o desenvolvimento somente se efetivarão por meio de uma ação política profunda e persistente. Como se trata de reconstrução estrutural, "a simples lógica do mercado é insuficiente. Somente uma visão global, traduzida em criterioso planejamento, poderá assegurar a transição para formas mais eficazes de utilização dos recursos disponíveis” (FURTADO, I983c, p. 42). Em linha com os escritos do interlúdio nordestino, o autor defende que a luta pela endogeneização do desenvolvimento exige a realização de amplas reformas estruturais, as quais somente serão concretizadas no quadro de um efetivo planejamento, que, por seu lado, deve apoiar-se em amplo consenso social, ou seja, assentar-se em bases genuinamente democráticas.

Esse esforço de reconstrução estrutural funda-se, conforme informa o pensamento furtadiano, numa racionalidade mais abrangente do que a dos mercados. Em suas próprias palavras: "esse trabalho de reconstrução de estruturas requer uma ação orientadora que somente pode vir do Estado. A complexidade da tarefa que cabe a este realizar exige uma visão global, sincrônica e diacrônica, que só se obtém com o planejamento" (FURTADO, I997a, p. 35). A isso cabe acrescentar que "não há política de desenvolvimento se a ação do Estado não se orienta de forma prioritária para a solução dos problemas sociais” (FURTADO, I983b, p. 64).

Ao referir-se ao projeto político como condição necessária para franquear a barreira do subdesenvolvimento, o autor resgata a noção mannheimiana de planejamento democrático, apresentando o planejamento como uma técnica que permite alcançar o desenvolvimento com o mínimo custo social. O objetivo dessa técnica social é "modificar estruturas bloqueadoras da dinâmica socioeconômica, tais como o latifundismo, o corporativismo, a canalização inadequada da poupança, o desperdício desta em formas abusivas de consumo e sua drenagem para o exterior" (FURTADO, I992a, p. 75). Em outro livro, o intelectual brasileiro complementa essa ideia, dizendo que o planejamento deve ser visto como "uma técnica que permite elevar o nível de racionalidade das decisões econômicas tanto nas empresas como em uma sociedade organizada politicamente" (FURTADO, I999b, p. 4I). E declara em seguida que "o planejamento aumenta a eficácia do Estado" (FURTADO, I999b, p. 80).

Em uma entrevista concedida a Álvaro Kassab, em 2004, o autor referenda a afirmação de que o Estado nacional é o instrumento privilegiado na luta contra o subdesenvolvimento, dizendo que "cabe ao Estado assumir o papel de condutor da política nos países subdesenvolvidos. É ele o instrumento privilegiado para enfrentar os problemas estruturais" (FURTADO, 2004, p. 3). Em outra ocasião, essas mesmas ideias são reforçadas pelo autor, quando alega que "o subdesenvolvimento somente pode ser superado mediante a adoção de um conjunto coerente de políticas públicas” (FURTADO, I999c, p. I2). Em síntese, tem-se que a superação do subdesenvolvimento requer intencionalidade, o que supõe um respaldo social e também um impulso político deliberado.

Por fim, ressalta-se que o autor reproduz a interpretação de Estado que desvelamos nas seções anteriores. Ao fazê-lo, destaca a importância de evitar pensar o Estado 
"como algo que existe por si mesmo e que se reproduz tal qual é” (FURTADO, I983a, p. 75). Em sintonia com a hipótese sustentada neste artigo, o autor argumenta que "é necessário não perder de vista que o Estado é principalmente a resultante de um conjunto de forças que mantêm a coesão social e definem a orientação do desenvolvimento" (FURTADO, I983a, p. 75). Nesse particular, conclui-se que os estudos que abordam o Estado não devem mantê-lo distante ou isolado das particularidades históricas, nem das estruturas sociais das quais ele é fruto e cimento.

\section{CONSIDERAÇõES FINAIS}

Ao longo deste artigo, objetivamos desvelar e sistematizar a evolução das ideias de Celso Furtado sobre Estado e planejamento, tendo como referência diferentes períodos da sua trajetória intelectual e política.

Conforme visto, os escritos de juventude (I944-I948) revelaram o que chamamos de concepção originária, a qual retrata o Estado sob as perspectivas instrumental e funcional-pragmática, sendo incomum qualquer aprofundamento teórico-conceitual, que leve em consideração a gênese, a formação, a estrutura e a evolução do Estado. Ou seja, a ênfase recaiu sobre o instrumento de ação, que é o planejamento.

Essa concepção de Estado foi reproduzida pelo autor nos escritos do interregno cepalino (I949-I958). Em consequência, temos que o Estado é uma presença-ausente na obra do autor, isto é, constitui um elemento sempre reivindicado, ocupando posição de destaque em suas reflexões, mas que não chega a se transformar em objeto de investigação preferencial.

Nos escritos do interlúdio nordestino (I959-I964) o autor conseguiu ir além das perspectivas instrumental e funcional-pragmática de Estado, superando, assim, a chamada concepção originária. Nesse sentido, foi possível demonstrar que, em Furtado, o Estado é visto como parte da sociedade e, ao mesmo tempo, expressão dessa mesma sociedade. Ou seja, constatamos que o Estado é, simultaneamente, "fruto" e "cimento" das estruturas sociais e econômicas. Assim, podemos concluir que Celso Furtado logrou ir além do "olhar dos economistas”, abandonando, portanto, a visão do Estado como um deus ex machina pairando acima da sociedade.

Os escritos de maturidade (I965-I980), por sua vez, revelaram uma preocupação constante de Celso Furtado com respeito à evolução estrutural do sistema capitalista na fase de predomínio das empresas transnacionais. Isso, porém, não significa que o autor abandonou a perspectiva que elege o Estado como causa e efeito dos processos de mudanças sociais. Apenas indica uma mudança de ênfase, ou seja, mostra que a preocupação do autor recaiu sobre outra problemática, cujo tratamento tornou-se mais premente para a compreensão dos problemas específicos que assolam as economias subdesenvolvidas na época contemporânea.

Os escritos finais (I98I-2004) trouxeram uma defesa da necessidade de fortalecer os mecanismos nacionais de regulação e coordenação como parte da estratégia de resistência ante as forças que operam planetariamente no sentido de desarticulação dos sistemas econômicos nacionais. Assim, em plena hegemonia do pensamento neoliberal, o autor insistiu que há espaço para a ação estatal assentada em efetivo 
planejamento na luta pelo desenvolvimento, não obstante vivermos em um mundo dominado por grupos transnacionais que fundam seu poder no controle da tecnologia, da informação e do capital financeiro.

Por fim, cumpre observar que o autor jamais deixou de reiterar a necessidade e a possibilidade de fortalecer e recuperar o Estado como centro coordenador e orientador de decisões econômicas estratégicas, posto que o verdadeiro desenvolvimento não resulta de forças que operam espontaneamente nos mercados, exigindo, ao contrário, um projeto político apoiado em amplos segmentos sociais. Para ele, a política nacional de desenvolvimento é ainda mais necessária no contexto do capitalismo global, não constituindo nenhum anacronismo, obsolescência ou retrocesso defendê-la e reivindicá-la.

\section{SOBRE O AUTOR}

RENATO NATANIEL WASQUES é professor adjunto

II e coordenador de Ensino de Graduação no Curso de Ciências Econômicas da Universidade Federal de Rondonópolis (UFR). wasques@ufr.edu.br https://orcid.org/oooo-0003-4846-7227

\section{REFERÊNCIAS}

BENOIT, H. Platão e as temporalidades: a questão metodológica. São Paulo: Annablume, 2015.

BIELSCHOWSKY, R. Pensamento econômico brasileiro: o ciclo ideológico do desenvolvimentismo (I930I964). 5. ed. Rio de Janeiro: Contraponto, 2004.

BRANDÃO, C. O compromisso com a (n)ação em Celso Furtado: notas sobre seu sistema teórico-analítico. Economia Ensaios, Uberlândia, v. 22, n. 2, p. 29-49, jan.-jul. 2008.

CEPÊDA, V. A. O pensamento político de Celso Furtado: desenvolvimento e democracia. In: BRESSER-PEREIRA, L. C.; REGO, J. M. (org.). A grande esperança em Celso Furtado. São Paulo: Ed. 34, 200I, p. I67-I84. D’AGUIAR, Rosa Freire. Introdução - Os anos de formação. In: FURTADO, Celso. Anos de formação - I938I948: o jornalismo, o serviço público, a guerra, o doutorado. Organização de Rosa Freire D’Aguiar. Rio de Janeiro: Contraponto/Centro Internacional Celso Furtado de Política para o Desenvolvimento, 20I4, p. 7- 28. (Arquivos Celso Furtado 6).

FURTADO, Celso. Formação de capital e desenvolvimento econômico. Revista Brasileira de Economia, Rio de Janeiro, v. 6, n. 3, set. I952, p. 7-45. Disponível em: http://bibliotecadigital.fgv.br/ojs/index.php/rbe/ article/view/2388/254I. Acesso em: ago. 2020.

FURTADO, Celso. Setor privado e poupança. Econômica Brasileira, Clube dos Economistas, Rio de Janeiro, v. 2, n. 2, abr.jun. I956, p. I00-IO2.

FURTADO, Celso. Desenvolvimento e subdesenvolvimento. Rio de Janeiro: Fundo de Cultura, I96I. 
FURTADO, Celso. Subdesenvolvimento e Estado democrático. Recife: Codepe, I962a.

FURTADO, Celso. A pré-revolução brasileira. Rio de Janeiro: Fundo de Cultura, I962b.

FURTADO, Celso. Dialética do desenvolvimento. Rio de Janeiro: Fundo de Cultura, I964.

FURTADO, Celso. Subdesenvolvimento e estagnação na América Latina. 3. ed. Rio de Janeiro: Civilização Brasileira, I968.

FURTADO, Celso. Um projeto para o Brasil. 5. ed. Rio de Janeiro: Saga, I969.

FURTADO, Celso. O mito do desenvolvimento econômico. 2. ed. Rio de Janeiro: Paz e Terra, I974.

FURTADO, Celso. Prefácio a nova economia política. Rio de Janeiro: Paz e Terra, I976.

FURTADO, Celso. O Brasil pós-“milagre”. 8. ed. Rio de Janeiro: Paz e Terra, I983a.

FURTADO, Celso. A nova dependência: dívida externa e monetarismo. 5. ed. Rio de Janeiro: Paz e Terra, I983b.

FURTADO, Celso. Não à recessão e ao desemprego. Rio de Janeiro: Paz e Terra, I983c.

FURTADO, Celso. Brasil: a construção interrompida. 3. ed. Rio de Janeiro: Paz e Terra, I992a.

FURTADO, Celso. Globalização das estruturas econômicas e identidade nacional. Estudos Avançados, São

Paulo, v. 6, I6, set.-dez. I992b, p. 55-64. Disponível em: https://www.scielo.br/pdf/ea/v6nI6/v6nI6a05. pdf. Acesso em: ago. 2020.

FURTADO, Celso. Entre inconformismo e reformismo. In: FURTADO, Celso. Obra autobiográfica. Tomo III. Organização de Rosa Freire d’Aguiar. Rio de Janeiro: Paz e Terra, I997a, p. II-40.

FURTADO, Celso. Os ares do mundo. In: FURTADO, Celso. Obra autobiográfica. Tomo III. Organização de Rosa Freire d'Aguiar. Rio de Janeiro: Paz e Terra, I997b, p. 4I-390.

FURTADO, Celso. A lição de um mestre. In: ABDE - Associação Brasileira de Instituições Financeiras de Desenvolvimento (org.). Lições de mestres: entrevistas sobre globalização e desenvolvimento econômico. Rio de Janeiro: Campus/ABDE, I998, p. 65-75. [Publicado originalmente na revista Rumos, ABDE, ano XX, n. I25, I996, p. 4-9.]

FURTADO, Celso. O capitalismo global. 3. ed. São Paulo: Paz e Terra, I999a.

FURTADO, Celso. O longo amanhecer: reflexões sobre a formação do Brasil. 2. ed. Rio de Janeiro: Paz e Terra, I999b.

FURTADO, Celso. Brasil: opções futuras. Revista de Economia Contemporânea, Rio de Janeiro, v. 3, n. 2, jul.-dez., I999C, p. 9-I5. Disponível em: https://revistas.ufrj.br/index.php/rec/article/view/I9599/II363. Acesso em: ago. 2020.

FURTADO, Celso. Teoria e política do desenvolvimento econômico. Io. ed. São Paulo: Paz e Terra, 2000.

FURTADO, Celso. Em busca de novo modelo: reflexões sobre a crise contemporânea. São Paulo: Paz e Terra, 2002.

FURTADO, Celso. A responsabilidade dos cientistas. Folha de S. Paulo, São Paulo, I3 jun. 2003, Caderno I, p. 3 .

FURTADO, Celso. Receita para o crescimento. [Entrevista concedida a] Álvaro Kassab. Jornal da Unicamp, Universidade Estadual de Campinas, 27 de setembro a 3 de outubro de 2004, p. 3.

FURTADO, Celso. Entrevista com o professor Celso Furtado. [Concedida a] Mário Theodoro. Revista Economia Ensaios, Uberlândia, v. 22, n. 2, p. 9-27, jan.jul. 2008a.

FURTADO, Celso. Entrevista concedida a Claudio Cerri. In: FURTADO, CELSO. Economia do desenvolvimento: curso ministrado na PUC-SP em I975. Rio de Janeiro: Contraponto: Centro Internacional Celso Furtado, p. 247-254, 2008b.

FURTADO, Celso. A estrutura da Comissão do Serviço Civil dos Estados Unidos. In: FURTADO, Celso. Anos de formação - I938-I948: o jornalismo, o serviço público, a guerra, o doutorado. Organização de Rosa 
Freire d'Aguiar. Rio de Janeiro: Contraponto/Centro Internacional Celso Furtado de Política para o Desenvolvimento, p. I2I-I29, 20I4a. (Arquivos Celso Furtado 6).

FURTADO, Celso. Notas sobre a administração de pessoal no governo federal americano. In: FURTADO, Celso. Anos de formação - I938-I948: o jornalismo, o serviço público, a guerra, o doutorado. Organização de Rosa Freire d'Aguiar. Rio de Janeiro: Contraponto/Centro Internacional Celso Furtado de Política para o Desenvolvimento, p. I3I-I/I, 20I4b. (Arquivos Celso Furtado 6).

FURTADO, Celso. A feição funcional da democracia moderna. In: FURTADO, Celso. Anos de formação I938-I948: o jornalismo, o serviço público, a guerra, o doutorado. Organização de Rosa Freire d’Aguiar. Rio de Janeiro: Contraponto/Centro Internacional Celso Furtado de Política para o Desenvolvimento, p. 207-2II, 20I4c. (Arquivos Celso Furtado 6).

FURTADO, Celso. Planificação e orçamento. In: FURTADO, Celso. Anos de formação - I938-I948: o jornalismo, o serviço público, a guerra, o doutorado. Organização de Rosa Freire d’Aguiar. Rio de Janeiro: Contraponto/Centro Internacional Celso Furtado de Política para o Desenvolvimento, p. I43-I49, 20I4d. (Arquivos Celso Furtado 6).

FURTADO, Celso. Organização do município moderno. In: FURTADO, Celso. Anos de formação - I938-I948: o jornalismo, o serviço público, a guerra, o doutorado. Organização de Rosa Freire d’Aguiar. Rio de Janeiro: Contraponto/Centro Internacional Celso Furtado de Política para o Desenvolvimento, p. I73-I78, 20I4e. (Arquivos Celso Furtado 6).

FURTADO, Celso. Teoria do Departamento de Administração Geral. In: FURTADO, Celso. Anos de formação - I938-I948: o jornalismo, o serviço público, a guerra, o doutorado. Organização de Rosa Freire d'Aguiar. Rio de Janeiro: Contraponto/Centro Internacional Celso Furtado de Política para o Desenvolvimento, p. I79-I95, 2014f. (Arquivos Celso Furtado 6).

FURTADO, Celso. Planificação social. In: FURTADO, Celso. Anos de formação - I938-I948: o jornalismo, o serviço público, a guerra, o doutorado. Organização de Rosa Freire d'Aguiar. Rio de Janeiro: Contraponto/Centro Internacional Celso Furtado de Política para o Desenvolvimento, p. 2I3-2I7, 20I4g. (Arquivos Celso Furtado 6).

FURTADO, Celso. Trajetória da democracia na América. In: FURTADO, Celso. Anos de formação - I938-I948: o jornalismo, o serviço público, a guerra, o doutorado. Organização de Rosa Freire d’Aguiar. Rio de Janeiro: Contraponto/Centro Internacional Celso Furtado de Política para o Desenvolvimento, p. 2I9-243, 20I/4h. (Arquivos Celso Furtado 6).

FURTADO, Celso. Diários intermitentes: I937-2002. Organização, apresentação e notas de Rosa Freire D’Aguiar. Prefácio de João Antonio de Paula. São Paulo: Companhia das Letras, 2019.

IGLÉSIAS, F. Celso Furtado, pensamento e ação. In: IGLÉSIAS, F. História e ideologia. São Paulo: Perspectiva, I97I, p. I59-234.

LOVE, J. Furtado e o estruturalismo. In: BRESSER-PEREIRA, L. C.; REGO, J. M. (org.). A grande esperança em Celso Furtado. São Paulo: Ed. 34, 200I, p. I57-I65.

MALLORQUIN, C. Celso Furtado: um retrato intelectual. São Paulo: Xamã: Rio de Janeiro: Contraponto, 2005.

MANNHEIM, K. O homem e a sociedade: estudos sobre a estrutura social moderna. Rio de Janeiro: Zahar, I962.

MANTEGA, G. A economia política brasileira. 2. ed. Petrópolis, RJ: Vozes; São Paulo: Polis, I984.

OLIVEIRA, F. Viagem ao olho do furacão: Celso Furtado e o desafio do pensamento autoritário brasileiro. In: OLIVEIRA, F. A navegação venturosa: ensaios sobre Celso Furtado. São Paulo: Boitempo, p. 59-82, 2003. 
PAULANI, L. M. A utopia da nação: esperança e desalento. In: BRESSER-PEREIRA, L. C.; REGO, J. M. (org.). A grande esperança em Celso Furtado. São Paulo: Ed. 34, 200I, p. I39-I56.

RICUPERO, B. Celso Furtado e o pensamento social brasileiro. Estudos Avançados, São Paulo, v. I9, n. 53, p. 37I-377, jan.-abr. 2005.

SAMPAIO JR., P. A. Furtado e os limites da razão burguesa na periferia do capitalismo. Economia Ensaios, Uberlândia, v. 22, n. 2, p. 69-98, jan.-jul. 2008.

SILVA, R. P. Celso Furtado e a administração pública: uma leitura de suas primeiras publicações (I944I948). História Unisinos, São Leopoldo, v. I4, n. I, p. 88-99, jan.-abr. 2010.

VIEIRA, R. M. Estado, racionalidade e planejamento. Revista de Administração de Empresas, São Paulo, v. 45, n. 2, p. 97-I04, abr.-jun. 2005.

WASQUES, R. N. Celso Furtado: intelectual reformista a serviço da (n)ação. Revista de Ciências Sociais, Fortaleza, v. 5I, n. I, p. I07-I53, mar.-jun. 2020.

WASQUES, R. N.; SANTOS JÚNIOR, W. L. S.; BRANDÃO, D. D. As ideias de Celso Furtado sobre a questão ambiental. Leituras de Economia Política, Campinas, v. I9, n. I (28), p. 4I-58, jan.jun. 2019. 